\title{
PENGARUH KONDISI LINGKUNGAN DAN MOTIVASI TERHADAP KEMANDIRIAN BELAJAR MAHASISWA POLITEKNIK NEGERI JEMBER
}

Oleh :

SITI AISYIYAH *)

\begin{abstract}
ABSTRAK
Kemandirian belajar mahasiswa sebagai generasi penerus bangsa perlu ditumbuhkan dan dikembangkan untuk meningkatkan kualitas sumber daya manusia Indonesia melalui penciptaan kondisi lingkungan yang kondusif dan peningkatan motivasi. Pelaksanaan penelitian ini ditujukan untuk mengetahui pengaruh kondisi lingkungan dan motivasi baik secara parsial maupun secara serempak terhadap kemandirian belajar mahasiswa Politeknik Negeri Jember. Sampel diambil dengan teknik sampling acak bertingkat. Pengambilan data dilakukan dengan menggunakan kuesioner untuk ketiga variabel yang telah dikalibrasi. Data yang diperoleh dianalisis secara deskriptif dan inferensial. Analisis deskriptif dilakukan untuk memperoleh gambaran secara umum dari hasil penelitian. Analisis inferensial dilakukan untuk meguji hipotesis dengan menggunakan analisis regresi baik secara parsial maupun berganda pada taraf sinifikansi 5\%. Analisis data dalam penelitian ini menunjukkan hasil sebagai berikut: (1) terdapat pengaruh yang signifikan dari kondisi lingkungan terhadap kemandirian belajar mahasiswa, (2) terdapat pengaruh yang signifikan dari motivasi terhadap kemandirian belajar mahasiswa, (3) terdapat pengaruh yang signifikan secara serempak dari kondisi lingkungan dan motivasi terhadap kemandirian belajar mahasiswa.
\end{abstract}

Kata Kunci: Kemandirian Belajar Mahasiswa, Kondisi Lingkungan, Motivasi 



\section{PENDAHULUAN}

Mahasiswa sebagai generasi penerus menjadi tumpuan harapan masa depan bangsa. Kondisi bangsa Indonesia yang semakin hari semakin memburuk membutuhkan penanganan yang serius dari generasi yang berkualitas. Masalah demi masalah yang terjadi tidak tertangani dengan baik, misalnya harga kebutuhan pokok yang melambung tinggi, pelayanan kesehatan yang buruk bagi masyarakat miskin, korupsi yang semakin menjamur, penegakan hukum yang tidak adil, kekerasan, tindak asusila, serta berbagai masalah lain. Generasi yang saat ini menjadi pengelola negara belum mampu memberi solusi yang tepat untuk mengatasi berbagai masalah tersebut. Oleh karena itu, diperlukan generasi yang handal untuk bisa mengatasi berbagai masalah di atas. Tentu saja harapan itu tertuju kepada para mahasiswa sebagai calon-calon pemimpin bangsa.

Sayangnya, kualitas sumber daya manusia Indonesia dewasa ini semakin terpuruk. Pendapat ini didasarkan pada peringkat indeks pembangunan manusia (human development index/HDI) yang dirilis oleh United Nations Development Program (UNDP) pada kurun waktu tiga tahun terakhir (2009 - 2011) yaitu 111,108 , dan 124 . Pada tahun 2011, Indonesia berada satu peringkat di bawah Afrika Selatan yang selama ini dianggap sebagai negara tertinggal. Peringkat ini disusun berdasarkan tiga kriteria yaitu harapan hidup, tingkat pendapatan/ekonomi, dan pendidikan. Hal ini diperparah oleh data pada tabel liga global yang diterbitkan oleh firma pendidikan Pearson yang menempatkan sistem pendidikan Indonesia pada peringkat terendah di dunia bersama Meksiko dan Brasil (Damanik, 2012). Peringkat tersebut disusun dengan memadukan hasil tes internasional dan data, seperti tingkat kelulusan, serta berdasarkan keberhasilan negara-negara memberikan status tinggi pada guru dan memiliki "budaya" pendidikan.

Kondisi tersebut menunjukkan bahwa sistem pendidikan di Indonesia masih belum mampu menghasilkan generasi yang berkualitas. Padahal kualitas sumber daya manusia merupakan prasyarat utama agar dapat bersaing dengan bangsa lain. Agar dapat menjadi manusia yang berkualitas, seseorang harus meningkatkan pengetahuan dan keterampilannya secara terus menerus sesuai dengan tuntutan zaman, dengan kata lain, ia perlu belajar sepanjang hidupnya atau menjadi seorang life long learner (Aisyiyah, 2012). Hal ini sejalan dengan kebutuhan dasar belajar (the basic learning needs), yaitu dapat mengembangkan dirinya secara optimal dan dapat belajar terus (Soedijarto, 2003).

Salah satu bekal utama agar menjadi seorang life long learner (orang yang belajar sepanjang hayat), adalah memiliki kemandirian belajar. Dalam belajar, kita tidak bisa hanya bergantung pada pendidik atau institusi pendidikan. Rasyid (2007) menyatakan bahwa tidak ada guru, sekolah, atau universitas yang dapat memenuhi semua kebutuhan belajar para peserta didik, sehingga mereka perlu memiliki kemandirian belajar. Di samping itu, dalam UU RI Nomor 20 Tahun 2003 tentang SISDIKNAS disebutkan "tujuan pendidikan nasional adalah mengembangkan potensi peserta didik agar menjadi manusia yang beriman dan bertaqwa kepada Tuhan YME, berakhlak mulia, sehat, berilmu, cakap, kreatif, mandiri, dan menjadi warga negara yang demokratis serta bertanggung jawab". Jadi, karakter 'mandiri' menjadi salah satu tujuan pendidikan nasional bangsa Indonesia.

Di sisi lain, rendahnya kualitas sumber daya manusia Indonesia menjadi salah satu indikator bahwa pendidikan nasional belum dapat mencetak generasi yang memiliki kemandirian belajar. Dengan kata lain, tingkat kemandirian belajar para peserta didikIndonesia masih perlu ditingkatkan.

Mengingat kemandirian belajar bukan merupakan bakat atau bawaan yang dibawa sejak lahir, kemandirian belajar tersebut harus ditumbuhkan dan dikembangkan dalam proses pendidikan. Shadiq (2008) menyebutkan bahwa faktor lembaga pendidikan sebagai lingkungan belajar, di samping faktor keluarga, juga perlu diperhatikan dalam pembentukan kemandirian belajar peserta didik. Oleh karena itu, perguruan tinggi termasuk Politeknik Negeri Jember sebagai salah satu lembaga pendidikan formal harus memperhatikan kondisi lingkungan yang kondusif untuk mengembangkan kemandirian belajar para mahasiswanya.

Yang tidak kalah pentingnya, faktor internal para mahasiswa tersebut, salah satunya adalah motivasi, juga perlu diperhatikan. Dengan memiliki motivasi yang baik, para mahasiswa diharapkan dapat melakukan aktivitas belajar berdasarkan inisiatif dan kemauannya sendiri tanpa terlalu bergantung pada kondisi eksternal. Motivasi untuk belajar ini adalah salah satu bekal penting untuk menumbuhkan dan mengembangkan kemandirian belajar mahasiswa. Berdasarkan uraian di atas, peneliti tertarik untuk mengetahui adanya pengaruh kondisi lingkungan dan motivasi terhadap kemandirian belajar mahasiswa Politeknik Negeri Jember. 
Masalah dalam penelitian ini dirumuskan sebagai berikut: (1) Bagaimana pengaruh kondisi lingkungan terhadap kemandirian belajar mahasiswa Politeknik Negeri Jember? (2) Bagaimana pengaruh motivasi terhadap kemandirian belajar mahasiswa Politeknik Negeri Jember? (3) Bagaimana pengaruh kondisi lingkungan dan motivasi secara serempak terhadap kemandirian belajar mahasiswa Politeknik Negeri Jember? Penelitian ini dilaksanakan untuk mengetahui pengaruh kondisi lingkungan dan motivasi terhadap kemandirian belajar mahasiswa baik secara parsial maupun secara serempak. Di samping itu, hasil penelitian ini juga dapat memberi masukan yang bermanfaat untuk mengadakan evaluasi berkaitan dengan kondisi lingkungan dan motivasi guna meningkatkan kemandirian belajar mahasiswa Politeknik Negeri Jember.

Hartoto (2008) mengartikan kemandirian dalam belajar sebagai aktivitas belajar yang berlangsung lebih didorong oleh kemauan sendiri, pilihan sendiri dan tanggung jawab sendiri dari peserta didik. Lebih lanjut Semiawan, dkk. seperti dikutip oleh Hartoto (2008) mengemukakan alasan pentingnya kemandirian dalam belajar, antara lain:

a. pesatnya perkembangan IPTEK;

b. relativitas kebenaran penemuan IPTEK;

c. pengalaman dan praktik secara langsung mempermudah memahami konsep-konsep yang rumit dan abstrak;

d. pengembangan sikap dan nilai-nilai harus diintegrasikan dalam proses pembelajaran.

Sedangkan menurut Thanasoulas (2008), secara umum istilah kemandirian dalam belajar digunakan berkaitan dengan:

a. kondisi di mana peserta didik dapat belajar sendiri secara total;

b. kemampuanyang dapat dipelajari dan diterapkan dalam proses belajar mandiri (selfdirected learning);

c. potensi/bakat yang tidak dapat disalurkan melalui institusi pendidikan;

d. latihan bagi peserta didik untuk bertanggung jawab atas proses belajarnya sendiri;

e. kesempatan bagi peserta didik untuk menentukan arah dari proses belajarnya sendiri.

Definisi lain dikemukakan oleh Little (2008) yang menyebutkan bahwa kemandirian belajar berkaitan dengan keterkaitan psikologis antara peserta didik dengan proses belajarnya, antara lain mencakup keteguhan sikap, refleksi kritis, pengambilan keputusan, dan tindakan mandiri. Hal ini berarti untuk mencapai kemandirian belajar, peserta didik harus memiliki wawasan, sikap posistif, kemampuan merefleksi, dan kesiapan untuk mengelola diri dan berinteraksi dengan peserta didik yang lain. Dengan kata lain, kemandirian belajar melibatkan aspek kognitif, metakognitif, afektif, dan sosial dalam proses belajar.

Aspek kognitif berkaitan kemampuan berpikir atau mental mahasiswa. Aspek metakognitif berkaitan dengan kemampuan untuk merefleksi kemampuan belajarnya sendiri. Olivier dan Bowler (1996) menyatakan bahwa aspek metakognitif mengacu pada kemampuan atau pengetahuan yang dimiliki oleh peserta didik tentang proses kognitifnya sendiri, tentang bagaimana cara belajarnya. Sedangkan menurut Wenden (1991) strategi metakognitif meliputi keterampilan untuk merencanakan, memonitor, serta mengevaluasi aktivitas belajar.

Aspek afektif, menurut Woolfolk (2004) mengacu pada sikap yang merupakan bagian dari persepsi, cara seseorang merespon sesuatu, motivasi dan nilai-nilai yang diyakini. Sikap juga berkaitan dengan self-esteem atau penghargaan terhadap diri sendiri, atau lebih dikenal dengan harga diri. Sementara itu, aspek sosial berkaitan dengan kemampuan seseorang dalam berinteraksi dengan lingkungannya, baik dengan pendidik maupun dengan peserta didik lain (Aisyiyah, 2012).

Ada lima tingkatan kemandirian peserta didik dalam belajar menurut Nunan seperti yang dikutip oleh Rasyid (2007), yaitu: Awareness, Involvement, Intervention, Creation, dan Transcendence. Awareness mengacu pada kesadaran mahasiswa untuk belajar. Involvement berkaitan dengan keterlibatan mahasiswa dalam memilih tujuan belajarnya. Intervention melibatkan kemampuan mengidentifikasi dan mengadaptasi tujuan dan bahan pembelajaran. Creation berarti mahasiswa mampu menentukan tujuan belajarnya sendiri. Sedangkan transcendence bermakna menghubungkan atau mengaitkan materi belajar di dalam kelas dengan dunia luar.

Dari uraian di atas dapat disimpulkan bahwa kemandirian belajar berarti kemampuan dan kemauan peserta didik untuk bertanggung jawab atas proses belajarnya dan berinisiatif dalam mengatasi masalah dan memenuhi kebutuhan untuk mencapai tujuan belajar.

Untuk menumbuhkan kemandirian belajar, diperlukan adanya kondisi lingkungan yang kondusif. Menurut Ahmadi dan Uhbiyati (2003) lingkungan adalah segala sesuatu yang berada di luar diri seseorang. Sementara itu Edge (1999) menyebutkan bahwa lingkungan yang mempengaruhi proses belajar menyangkut aspek 
Siti Aisyiyah, Pengaruh Kondisi Lingkungan Dan Motivasi Terhadap Kemandirian Belajar Mahasiswa

Politeknik Negeri Jember

fisik dan psikologis di mana peserta didik berinteraksi dengan pendidik. Aspek fisik antara lain meliputi kondisi ruangan, alat-alat atau media. Sedangkan aspek psikologis berkaitan dengan kondisi psikologis hubungan antara peserta didik dengan pendidik.

Di sisi lain, Djamarah (2008) menyebutkan bahwa lingkungan terbagi atas dua macam, yaitu lingkungan alami dan lingkungan sosial budaya. Lingkungan alami berkaitan dengan kondisi alam di sekitar tempat belajar. Sedangkan lingkungan sosial budaya berkaitan dengan kondisi sosial budaya di sekitar tempat belajar. Oleh karena itu, pembangunan tempat belajar sebaiknya berwawasan lingkungan dan memperhatikan kondisi sosial budaya di sekitarnya.

Sedangkan proses pembelajaran pada sebuah lembaga pendidikan, menurut Hakim (2000), dipengaruhi oleh beberapa faktor antara lain: tegaknya kedisiplinan yang konsisten, adanya pendidik yang kompeten, kondisi gedung yang nyaman, serta tersedianya fasilitas untuk belajar yang memadai.

Faktor lain yang dapat mempengaruhi proses pembelajaran, menurut Sanjaya (2007), dapat dilihat dari aspek lingkungan, yaitu faktor organisasi kelas dan faktor iklim sosial-psikologis. Faktor organisasi kelas, yang berkaitan dengan jumlah mahasiswa dalam satu kelas, merupakan aspek penting yang bisa mempengaruhi proses pembelajaran. Organisasi kelas yang terlalu besar akan kurang efektif untuk mencapai tujuan pembelajaran. Sedangkan faktor iklim sosialpsikologis berkaitan dengan keharmonisan hubungan antara orang-orang yang terlibat dalam proses pembelajaran.

Dari penjelasan di atas dapat disimpulkan bahwa kondisi lingkungan mengacu pada kondisi tempat berlangsungnya proses pembelajaran di kampus yang menyangkut aspek fisik dan non fisik. Sedangkan faktor-faktor yang mempengaruhi lingkungan belajar antara lain meliputi kedisiplinan, kondisi gedung dan fasilitas, peran pendidik, dan iklim sosial psikologis.

Di sisi lain, salah satu faktor internal yang berkaitan dengan kemandirian belajar mahasiswa adalah motivasi. Menurut Woolfolk (2004), motivasi mengacu pada kondisi internal yang mendorong, mengarahkan dan memelihara perilaku seseorang. Sementara itu, Keller dan Litchfield (2002) menyebutkan, "motivasi mengacu pada hasrat seseorang untuk meraih tujuan atau melakukan suatu aktivitas, yang diwujudkan dalam bentuk upaya (ketekunan serta kekuatan) untuk mencapai tujuan tersebut". Sardiman (2008) mengatakan, "istilah motivasi berasal dari kata motif yang berarti daya penggerak dari dalam dan di dalam subjek untuk melakukan aktivitas-aktivitas tertentu demi mencapai suatu tujuan".

Motivasi ini berperan sangat penting dalam proses pembelajaran. Sardiman (2008) menyebutkan beberapa fungsi motivasi. Fungsi pertama adalah untuk mendorong peserta didik untuk berbuat, jadi sebagai penggerak atau motor yang melepaskan energi. Fungsi kedua adalah untuk menentukan arah perbuatan, yakni ke arah tujuan yang hendak dicapai. Dengan demikian motivasi dapat memberikan arah dan kegiatan yang harus dikerjakan sesuai dengan tujuannya. Fungsi ketiga berguna untuk menyeleksi perbuatan, yaitu menentukan perbuatan apa yang harus dilakukan untuk mencapai tujuan, dengan meninggalkan perbuatan yang tidak bermanfaat.

Ada berbagai macam jenis motivasi, namun secara ringkas motivasi dapat dibedakan ke dalam dua jenis yaitu motivasi intrinsik dan motivasi ekstrinsik (Moore, 2005). Motivasi intrinsik merupakan motivasi yang berasal dari dalam diri peserta didik tanpa dipengaruhi faktor dari luar. Sedangkan motivasi ekstrinsik adalah motivasi yang muncul karena adanya faktor-faktor dari luar diri peserta didik, yaitu dari lingkungan.

Pada dasarnya, motivasi yang mendorong seseorang untuk melakukan sesuatu berkaitan dengan adanya kebutuhan yang tidak terpenuhi. Hal ini sesuai dengan apa yang dikemukakan oleh Abraham Maslow dalam teori kebutuhan. Teori Maslow yang dikutip oleh Kotze (2008) menyebutkan bahwa seseorang memiliki motivasi untuk memenuhi beberapa macam kebutuhan yang berbeda, yaitu kebutuhan fisiologis, kebutuhan keamanan, kebutuhan sosial, kebutuhan harga diri, dan kebutuhan aktualisasi diri. Sedangkan menurut Woolfolk (2004), faktor-faktor personal yang mempengaruhi motivasi antara lain orientasi tujuan, minat dan emosi, serta self-schemas atau keyakinan peserta didik terhadap dirinya sendiri. Dalam proses pembelajaran, ada beberapa macam motivasi yang dapat diberikan kepada peserta didik, antara lain memberi angka atau nilai, hadiah, kompetisi, ego-involvement (harga diri peserta didik), memberi ulangan, mengetahui hasil, pujian, hukuman, hasrat untuk belajar, minat, serta tujuan yang diakui (Djamarah, 2008).

Sementara itu Sardiman (2008) menyebutkan beberapa karakteristik individu yang memiliki motivasi untuk belajar antara lain tekun menghadapi tugas, ulet menghadapi kesulitan, tidak memerlukan dorongan dari luar untuk berprestasi sebaik mungkin, tidak cepat puas dengan prestasi yang telah dicapainya, menunjukkan minat terhadap berbagai macam masalah, lebih senang belajar mandiri,cepat bosan pada tugas-tugas yang rutin, dapat 
mempertahankan pendapatnya, tidak mudah melepaskan hal yang diyakini, serta senang mencari dan memecahkan soal-soal.

Dengan demikian dapat disimpulkan bahwa yang dimaksud dengan motivasi adalah daya penggerak yang mendorong, mengarahkan, dan mempertahankan peserta didik untuk melakukan aktivitas belajar.

Berdasarkan uraian di atas, hipotesis penelitian ini dirumuskan sebagai berikut: (1) Kondisi lingkungan berpengaruh terhadap kemandirian belajar mahasiswa. (2) Motivasi berpengaruh terhadap kemandirian belajar mahasiswa. (3) Kondisi lingkungan dan motivasi secara serempak berpengaruh terhadap kemandirian belajar mahasiswa.

\section{METODOLOGI PENELITIAN}

Penelitian ini merupakan penelitian kuantitatif yang menggunakan metode survei. Penelitian kuantitatif, menurut Sugiyono (2006), adalah penelitian yang bertujuan untuk menguji hipotesis yang telah ditetapkan. Dengan demikian, penelitian ini dimaksudkan untuk membuktikan adanya pengaruh kondisi lingkungan dan motivasi terhadap kemandirian belajar mahasiswa Politeknik NegeriJember baik secara parsial maupun secara serempak. Dalam penelitian ini, terdapat dua variabel bebas yaitu kondisi lingkungan $\left(\mathrm{X}_{1}\right)$ dan motivasi $\left(\mathrm{X}_{2}\right)$, serta satu variabel terikat yaitu kemandirian belajar mahasiswa (Y). Penelitian ini dilaksanakan di Politeknik Negeri Jember pada semester gasal tahun akademik 2012/2013.

Populasi target dari penelitian ini adalah seluruh mahasiswa Politeknik Negeri Jember tahun akademik 2012/2013. Populasi terjangkau adalah mahasiswa jurusan Bahasa, Komunikasi dan Pariwisata, jurusan Manajemen Agribisnis, jurusan Kesehatan, jurusan Teknologi Pertanian, jurusan Teknologi Informasi, dan jurusan Produksi Pertanian tahun akademik 2012/2013. Keenam jurusan ini dipilih secara acak dari semua jurusan yang ada di Politeknik Negeri Jember. Sampel dalam penelitian ini diambil dari satu kelas dari setiap jurusan yang terpilih dengan teknik sampling acak bertingkat. Menurut Arikunto (2007), teknik ini dapat dipergunakan apabila di dalam populasi terdapat kelompok-kelompok subjek. Pengambilan sampel dimulai dengan pemilihan jurusan di Politeknik Negeri Jember yang dilakukan secara acak, diperoleh jurusan Bahasa, Komunikasi dan Pariwisata, jurusan Manajemen Agribisnis, jurusan Kesehatan, jurusan Teknologi Pertanian, jurusan Teknologi Informasi, dan jurusan Produksi Pertanian. Setelah itu dipilih satu kelas dari setiap jurusan tersebut dengan pertimbangan teknis. Secara teknis, pemilihan kelas tersebut dapat terjangkau oleh peneliti dalam waktu yang cukup terbatas. Rata-rata jumlah mahasiswa yang diambil dalam satu kelas dari tiap jurusan adalah 20 orang. Jadi jumlah sampel dalam penelitian ini adalah 120 orang.

Pengumpulan data dalam penelitian ini dilakukan dengan menggunakan instrumen berupa kuesioner untuk ketiga variabel yang diteliti. Kuesioner merupakan daftar pertanyaan atau pernyataan yang diberikan kepada sampel penelitian atau responden dengan maksud agar responden tersebut bersedia memberikan respons sesuai dengan permintaan pengguna (Muhidin dan Abdurrahman, 2007). Ketiga instrumen tersebut telah melalui proses kalibrasi yaitu pengujian validitas dan reliabilitas. Pengujian validitas meliputi pengujian validitas konstruk, yaitu konsep instrumen diperiksa oleh tenaga ahli untuk mengetahui seberapa jauh butir-butir instrumen tersebut dapat mengukur dimensi dan indikator variabel yang diteliti, serta pengujian validitas butir instrumen dengan menggunakan rumus Product Moment dari Karl Pearson. Pengujian reliabilitas dilakukan pada butir yang valid dengan menggunakan rumus Alpha Cronbach. Berdasarkan pengujian validitas dan reliabilitas instrumen tersebut diperoleh instrumen variabel kemandirian belajar yang terdiri atas 40 butir pernyataan, instrumen variabel kondisi lingkungan berisi 33 butir pernyataan, serta instrumen variabel motivasi memuat 41 butir pernyataan.

Selanjutnya data yang didapat melalui penyebaran kuesioner tersebut dianalisis secara deskriptif dan inferensial. Analisis deskriptif dilakukan untuk memperoleh gambaran umum hasil penelitian. Dalam tahap ini data disajikan dalam statistik deskriptif seperti perhitungan mean, median, modus, simpangan baku (standar deviasi) dan rentang teoretik masing-masing variabel. Sedangkan analisis inferensial dilakukan untuk menguji hipotesis setelah dilakukan uji persyaratan analisis data, yaitu uji normalitas dan uji homogenitas. Uji normalitas dilakukan dengan menggunakan One Sample Kolmogorov-Smirnov, sedangkan uji homogenitas dilakukan dengan menggunakan One Way Anova. Pengujian hipotesis dilakukan dengan menggunakan analisis regresi baik secara parsial maupun berganda pada taraf signifikan $5 \%$. Hipotesis statistik dari penelitian ini adalah sebagai berikut:
1. $\quad \begin{array}{ll}\mathrm{H}_{0} & : \mathrm{p}_{\mathrm{y} 1}=0 \\ \mathrm{H}_{1} & : \mathrm{p}_{\mathrm{y} 1} \neq 0\end{array}$
$\mathrm{p}_{\mathrm{y} 1} \quad$ : koefisien regresi pengaruh kondisi lingkungan terhadap kemandirian belajar mahasiswa 
Siti Aisyiyah, Pengaruh Kondisi Lingkungan Dan Motivasi Terhadap Kemandirian Belajar Mahasiswa

Politeknik Negeri Jember

$$
\text { 2. } \quad \begin{array}{ll}
\mathrm{H}_{0} & : \mathrm{p}_{\mathrm{y} 2}=0 \\
\mathrm{H}_{1} & : \mathrm{p}_{\mathrm{y} 2} \neq 0 \\
\mathrm{p}_{\mathrm{y} 2} & : \begin{array}{l}
\text { koefisien regresi pengaruh } \\
\text { motivasi terhadap kemandirian } \\
\end{array} \\
& \\
& \text { belajar mahasiswa }
\end{array}
$$

\section{HASIL PENELITIAN}

Data penelitian diperoleh dari 120 responden yang dipilih secara acak. Setiap responden diminta untuk menjawab butir-butir pernyataan dalam kuesioner dari tiga variabel penelitian, yaitu satu varibel terikat kemandirian belajar mahasiswa (Y), dan dua variabel bebas yaitu kondisi lingkungan $\left(\mathrm{X}_{1}\right)$ dan motivasi $\left(\mathrm{X}_{2}\right)$. Untuk mendapatkan gambaran statistik dari ketiga variabel tersebut, terlebih dahulu dilakukan analisis statistik deskriptif untuk mendapatkan nilai rata-rata (mean), nilai tengah (median), nilai yang paling sering muncul (modus), simpangan baku (standar deviasi), dan varians. Berdasarkan hasil analisis statistik deskriptif diperoleh data sebagai berikut:

Tabel 1. Hasil Analisis

Statistik Deskriptif

\begin{tabular}{|c|c|r|r|r|}
\hline \multicolumn{2}{|c|}{} & \multicolumn{1}{|c|}{$\begin{array}{c}\text { Kemandirian } \\
\text { Belajar }\end{array}$} & $\begin{array}{c}\text { Kondisi } \\
\text { Lingkung } \\
\text { an }\end{array}$ & Motivasi \\
\hline \multirow{2}{*}{$\mathrm{n}$} & Valid & 120 & 120 & 120 \\
\cline { 2 - 5 } & $\begin{array}{l}\text { Missi } \\
\text { ng }\end{array}$ & 0 & 0 & 0 \\
\hline Mean & 4.178 & 3.960 & 4.148 \\
\hline Median & 4.200 & 3.900 & 4.100 \\
\hline Modus & 4.2 & 3.8 & 4.0 \\
\hline Standar Deviasi & .3053 & .3688 & .3425 \\
\hline Varians & .093 & .136 & .117 \\
\hline Rentang & 1.5 & 2.8 & 2.2 \\
\hline Minimum & 3.5 & 2.7 & 3.2 \\
\hline Maksimum & 5.0 & 5.5 & 5.4 \\
\hline
\end{tabular}

Dalam hipotesis pertama tentang pengaruh variabel kondisi lingkungan $\left(\mathrm{X}_{1}\right)$ terhadap kemandirian belajar mahasiswa (Y) telah dikemukakan hipotesis nol $\left(\mathrm{H}_{0}\right)$ : $\mathrm{p}_{\mathrm{y} 1}=0$, dan hipotesis alternatif $\left(\mathrm{H}_{1}\right): \mathrm{p}_{\mathrm{y} 1} \neq 0$, di mana $\mathrm{p}_{\mathrm{y} 1}$ adalah pengaruh $\mathrm{X}_{1}$ terhadap $\mathrm{Y}$. Dari hasil analisis regresi sederhana variabel $\mathrm{X}_{1}$ terhadap $\mathrm{Y}$ diperoleh harga $\mathrm{a}=2,408$ dan $\mathrm{b}=0,447$, sehingga berdasarkan persamaan regresi sederhana $\mathrm{Y}=\mathrm{a}+$ b $\mathrm{X}_{1}$ diperoleh persamaan $\mathrm{Y}=2,408+0,447 \mathrm{X}_{1}$.

Selanjutnya dilakukan uji koefisien regresi secara parsial yang dipergunakan untuk menguji apakah koefisien regresi dari variabel bebas kondisi lingkungan $\left(\mathrm{X}_{1}\right)$ mempunyai pengaruh secara parsial terhadap kemandirian belajar mahasiswa (Y). Apabila nilai probabilitas t lebih besar dari level of significance $(\alpha)$, maka $\mathrm{H}_{0}$ diterima dan $\mathrm{H}_{1}$ ditolak artinya variabel bebas tidak berpengaruh terhadap variabel terikat. Sebaliknya, apabila nilai probabilitas t lebih kecil level of significance $(\alpha)$, maka $\mathrm{H}_{0}$ ditolak dan $\mathrm{H}_{1}$ diterima artinya variabel bebas berpengaruh terhadap variabel terikat.

Dari hasil analisis regresi parsial dapat dilihat bahwa variabel bebas kondisi lingkungan $\left(\mathrm{X}_{1}\right)$ memiliki nilai probabilitas $\mathrm{t}$ sebesar 0,000 yang lebih kecil dari level of significance $(\alpha=$ 0,05), maka $\mathrm{H}_{0}$ ditolak dan $\mathrm{H}_{1}$ diterima sehingga variabel kondisi lingkungan $\left(\mathrm{X}_{1}\right)$ berpengaruh secara parsial terhadap kemandirian belajar mahasiswa (Y).

Uji signifikansi koefisien regresi parsial dapat dilakukan dengan membandingkan nilai $\mathrm{t}$ hitung dengan nilai $t$ tabel dengan kriteria apabila nilai $t_{\text {hitung }}>$ nilai $t_{\text {tabel }}$ berarti terdapat pengaruh yang signifikan. Sebaliknya jika nilai $t_{\text {hitung }}<$ nilai $t_{\text {tabel }}$ berarti pengaruh tidak signifikan. Dari hasil uji signifikansi koefisien regresi parsial diperoleh nilai $\mathrm{t}_{\text {hitung }}=6,965$ dan nilai $\mathrm{t}$ tabel pada taraf signifikansi 0,05 untuk uji 2 sisi adalah $t_{\text {tabel }}=1,9799$. Nilai $\mathrm{t}_{\text {hitung }}=6,965>\mathrm{t}_{\text {tabel }}=1,9799$ berarti pengaruh kondisi lingkungan $\left(\mathrm{X}_{1}\right)$ terhadap kemandirian belajar mahasiswa (Y) adalah signifikan dan positif, sehingga semakin baik kondisi lingkungan semakin baik pula kemandirian belajar mahasiswa. Rangkuman hasil uji signifikansi tersebut dapat dilihat dalam tabel berikut:

Tabel 2. Hasil Uji Signifikansi Pengaruh $\mathrm{X}_{1}$ terhadap Y

\begin{tabular}{|c|c|c|c|c|}
\hline $\begin{array}{c}\text { Koefisien } \\
\text { Regresi }\end{array}$ & $\begin{array}{c}\text { Koefisien } \\
\text { Determin } \\
\text { asi }\end{array}$ & $\mathbf{t}_{\text {hitung }}$ & $\begin{array}{c}\mathbf{t}_{\text {tabel }} \\
(\boldsymbol{\alpha}=\mathbf{0 , 0 2 5})\end{array}$ & Kesimpulan \\
\hline 0,540 & 0,291 & 6,625 & 1,9799 & $\begin{array}{c}\text { Pengaruh } \\
\text { signifikan }\end{array}$ \\
\hline
\end{tabular}

Koefisien determinasi sebesar 0,291 menunjukkan bahwa 29,1\% kemandirian belajar mahasiswa ditentukan oleh kondisi lingkungan $\left(\mathrm{X}_{1}\right)$ setelah motivasi mahasiswa $\left(\mathrm{X}_{2}\right)$ dikontrol.

Berdasarkan hasil analisis di atas dapat disimpulkan bahwa hipotesis alternatif $\left(\mathrm{H}_{1}\right)$ diterims. Hal ini berarti terdapat pengaruh positif dari kondisi lingkungan terhadap kemandirian belajar mahasiswa.

Dalam hipotesis kedua tentang pengaruh variabel motivasi $\left(\mathrm{X}_{2}\right)$ terhadap kemandirian belajar mahasiswa (Y) telah dikemukakan hipotesis nol $\left(\mathrm{H}_{0}\right): \mathrm{p}_{\mathrm{y} 2}=0$, dan hipotesis alternatif $\left(\mathrm{H}_{1}\right): \mathrm{p}_{\mathrm{y} 2} \nRightarrow 0$, di mana $\mathrm{p}_{\mathrm{y} 2}$ adalah pengaruh $\mathrm{X}_{2}$ terhadap Y. Dari hasil analisis regresi sederhana 
variabel $\mathrm{X}_{2}$ terhadap $\mathrm{Y}$ diperoleh harga $\mathrm{a}=1,572$ dan $b=0,628$, sehingga berdasarkan persamaan regresi sederhana $\mathrm{Y}=\mathrm{a}+\mathrm{b} \mathrm{X}_{2}$ diperoleh persamaan $\mathrm{Y}=1,572+0,628 \mathrm{X}_{2}$.

Selanjutnya dilakukan uji koefisien regresi secara parsial yang dipergunakan untuk menguji apakah koefisien regresi dari variabel bebas motivasi $\left(\mathrm{X}_{2}\right)$ mempunyai pengaruh secara parsial terhadap kemandirian belajar mahasiswa (Y). Apabila nilai probabilitas t lebih besar dari level of significance $(\alpha)$, maka $\mathrm{H}_{0}$ diterima dan $\mathrm{H}_{1}$ ditolak artinya variabel bebas tidak berpengaruh terhadap variabel terikat. Sebaliknya, apabila nilai probabilitas t lebih kecil level of significance $(\alpha)$, maka $\mathrm{H}_{0}$ ditolak dan $\mathrm{H}_{1}$ diterima artinya variabel bebas berpengaruh terhadap variabel terikat.

Dari hasil analisis regresi parsial dapat dilihat bahwa variabel bebas motivasi $\left(\mathrm{X}_{2}\right)$ memiliki nilai probabilitas $\mathrm{t}$ sebesar 0,000 yang lebih kecil dari level of signifikance $(\alpha=0,05)$, maka $\mathrm{H}_{0}$ ditolak dan $\mathrm{H}_{1}$ diterima sehingga variabel motivasi $\left(\mathrm{X}_{2}\right)$ berpengaruh secara parsial terhadap kemandirian belajar mahasiswa (Y).

Uji signifikansi koefisien regresi parsial dapat dilakukan dengan membandingkan nilai $\mathrm{t}$ hitung dengan nilai $t_{\text {tabel }}$ dengan kriteria apabila nilai $\mathrm{t}_{\text {hitung }}>$ nilai $\mathrm{t}_{\text {tabel }}$ berarti terdapat pengaruh yang signifikan. Sebaliknya jika nilai $t_{\text {hitung }}<$ nilai $t_{\text {tabel }}$ berarti pengaruh tidak signifikan. Uji signifikansi menunjukkan nilai $\mathrm{t}_{\text {hitung }}=10,791$ dan nilai $\mathrm{t}_{\text {tabel }}$ pada taraf signifikansi 0,05 untuk uji 2 sisi adalah $t$ tabel $=1,9799$. Nilai $\mathrm{t}$ hitung $=10,791>\mathrm{t}$ tabel $=$ 1,9799. Hal ini berarti pengaruh motivasi $\left(\mathrm{X}_{2}\right)$ terhadap kemandirian belajar mahasiswa (Y) adalah signifikan dan positif, sehingga semakin tinggi motivasi mahasiswa semakin tinggi pula tingkat kemandirian belajarnya. Rangkuman hasil uji signifikansi tersebut dapat dilihat dalam tabel berikut:

\begin{tabular}{|c|c|c|c|c|}
\hline $\begin{array}{c}\text { Koefisien } \\
\text { Regresi }\end{array}$ & $\begin{array}{c}\text { Koefisien } \\
\text { Determinasi }\end{array}$ & $\mathbf{t}_{\text {hitung }}$ & $\begin{array}{c}\mathbf{t}_{\text {tabel }} \\
\mathbf{\alpha = 0 , 0} \\
\mathbf{2 5}\end{array}$ & Kesimpulan \\
\hline 0,705 & 0,497 & $\begin{array}{c}10,79 \\
1 * *\end{array}$ & 1,9799 & $\begin{array}{c}\text { Pengaruh } \\
\text { sangat } \\
\text { signifikan }\end{array}$ \\
\hline
\end{tabular}

Tabel 3. Hasil Uji Signifikansi Pengaruh $X_{2}$ terhadap $Y$

Koefisien determinasi sebesar 0,497 menunjukkan bahwa 49,7\% kemandirian belajar mahasiswa ditentukan oleh motivasi mahasiswa $\left(\mathrm{X}_{2}\right)$ setelah kondisi lingkungan $\left(\mathrm{X}_{1}\right)$ dikontrol.

Berdasarkan hasil analisis di atas dapat disimpulkan bahwa hipotesis alternatif $\left(\mathrm{H}_{1}\right)$ diterima. Hal ini berarti terdapat pengaruh positif dari motivasi terhadap kemandirian belajar mahasiswa.

Dalam hipotesis ketiga tentang pengaruh variabel kondisi lingkungan $\left(\mathrm{X}_{1}\right)$ dan motivasi $\left(\mathrm{X}_{2}\right)$ secara serempak terhadap kemandirian belajar mahasiswa (Y) telah dikemukakan hipotesis nol $\left(\mathrm{H}_{0}\right): \mathrm{p}_{\mathrm{y} .12}=0$, dan hipotesis alternatif $\left(\mathrm{H}_{1}\right): \mathrm{p}_{\mathrm{y} .12} \neq$ 0 , di mana $\mathrm{p}_{\mathrm{y} .12}$ adalah pengaruh $\mathrm{X}_{1}$ dan $\mathrm{X}_{2}$ secara serempak terhadap Y. Pengujian hipotesis ketiga dilakukan dengan menggunakan analisis regresi berganda. Berikut ini adalah hasil analisis regresi berganda variabel $\mathrm{X}_{1}$ dan $\mathrm{X}_{2}$ terhadap $\mathrm{Y}$.

Berdasarkan hasil analisis regresi berganda diperoleh harga $\mathrm{a}=1,163, \mathrm{~b}_{1}=0,221$ dan $b_{2}=0,516$, sehingga berdasarkan persamaan regresi sederhana $\mathrm{Y}=\mathrm{a}+\mathrm{b}_{1} \mathrm{X}_{1}+\mathrm{b}_{2} \mathrm{X}_{2}$ diperoleh persamaan $\mathrm{Y}=1,163+0,221 \mathrm{X}_{1}+0,516 \mathrm{X}_{2}$.

Selanjutnya dilakukan analisis regresi berganda variabel kondisi lingkungan $\left(\mathrm{X}_{1}\right)$ dan belajar $\left(\mathrm{X}_{2}\right)$ secara serempak terhadap kemandirian belajar mahasiswa (Y). Dari hasil analisis diketahui bahwa probabilitas $F$ sebesar 0,000 yang menunjukkan bahwa probabilitas $\mathrm{F}$ lebih kecil dari level of significance $(\alpha=0,05)$, maka $\mathrm{H}_{0}$ ditolak dan $\mathrm{H}_{1}$ diterima, yang berarti variabel kondisi lingkungan $\left(\mathrm{X}_{1}\right)$ dan motivasi $\left(\mathrm{X}_{2}\right)$ secara serempak berpengaruh terhadap kemandirian belajar mahasiswa (Y).

Uji signifikansi dilakukan dengan membandingkan nilai $F_{\text {hitung }}$ dengan nilai $F_{\text {tabel. }}$ Jika nilai $F_{\text {hitung }}$ lebih besar daripada nilai $F_{\text {tabel, }}$ berarti pengaruh veariabel bebas terhadap variabel terikat signifikan. Hasil uji signifikansi menunjukkan nilai $F_{\text {hitung }}=72,085$ dan nilai $F_{\text {tabel }}$ pada taraf signifikasi 5\% adalah 3,07. Nilai $F_{\text {hitung }}$ $=72,085>\mathrm{F}_{\text {tabel }}=3,07$ berarti regresi $\mathrm{Y}$ atas $\mathrm{X}_{1}$ dan $\mathrm{X}_{2}$ adalah signifikan. Dengan demikian dapat disimpulkan bahwa pengaruh kondisi lingkungan $\left(\mathrm{X}_{1}\right)$ dan motivasi $\left(\mathrm{X}_{2}\right)$ secara serempak terhadap kemandirian belajar mahasiswa (Y) adalah signifikan. Rangkuman hasil uji signifikansi tersebut dapat dilihat pada tabel berikut:

Tabel 4. Hasil Uji Signifikansi Pengaruh $\mathbf{X}_{\mathbf{1}}$ dan $\mathbf{X}_{2}$ terhadap $\mathbf{Y}$
\begin{tabular}{|c|c|c|c|c|}
\hline $\begin{array}{c}\text { Koefisien } \\
\text { Regresi }\end{array}$ & $\begin{array}{c}\text { Koefi } \\
\text { sien } \\
\text { Deter } \\
\text { mina } \\
\text { si }\end{array}$ & $\mathbf{F}_{\text {hitung }}$ & $\begin{array}{c}\mathbf{F}_{\text {tabel }} \\
\boldsymbol{\alpha}= \\
\mathbf{0 , 0 5}\end{array}$ & Kesimpulan \\
\hline 0,743 & 0,552 & $72,085^{* *}$ & 3,07 & $\begin{array}{c}\text { Pengaruh } \\
\text { sangat } \\
\text { signifikan }\end{array}$ \\
\hline
\end{tabular}

Dari tabel di atas diketahui bahwa nilai koefisien regresi ganda $\mathrm{R}_{\mathrm{Y} .12}=0,743$ dan koefisien determinasi $\mathrm{R}^{2} \mathrm{Y} \cdot 12=0,552$. Koefisien determinasi sebesar 0,552 menunjukkan bahwa 55,2\% kemandirian belajar mahasiswa ditentukan oleh kondisi lingkungan dan motivasi mahasiswa secara 
Siti Aisyiyah, Pengaruh Kondisi Lingkungan Dan Motivasi Terhadap Kemandirian Belajar Mahasiswa

Politeknik Negeri Jember

serempak. Nilai koefisien yang positif menunjukkan arah pengaruh yang positif pula.

Berdasarkan hasil analisis di atas dapat disimpulkan bahwa hipotesis alternatif $\left(\mathrm{H}_{1}\right)$ diterima. Hal ini berarti terdapat pengaruh yang signifikan dan positif dari kondisi lingkungan dan motivasi secara serempak terhadap kemandirian belajar mahasiswa. Artinya semakin baik kondisi lingkungan yang diikuti dengan motivasi yang semakin tinggi, maka semakin tinggi pula kemandirian belajar mahasiswa.

\section{PEMBAHASAN}

Berdasarkan pengujian hipotesis yang dilakukan terhadap data hasil penelitian, diketahui bahwa ketiga hipotesis yang diajukan dalam penelitian ini teruji kebenarannya. Pengaruh variabel bebas terhadap variabel terikat, yaitu kondisi lingkungan $\left(\mathrm{X}_{1}\right)$ terhadap kemandirian belajar mahasiswa $(\mathrm{Y})$, motivasi $\left(\mathrm{X}_{2}\right)$ terhadap kemandirian belajar mahasiswa $(\mathrm{Y})$, serta kondisi lingkungan $\left(\mathrm{X}_{1}\right)$ dan motivasi $\left(\mathrm{X}_{2}\right)$ secara serempak terhadap kemandirian belajar mahasiswa (Y) bersifat signifikan. Hal ini berarti bahwa kondisi lingkungan dan motivasi sebagai variabel bebas sangat menentukan tingkat kemandirian belajar mahasiswa sebagai variabel terikat.

Selanjutnya pengaruh variabel bebas dan variabel terikat tersebut dapat dijelaskan sebagai berikut. Dari hasil analisis data terlihat bahwa terdapat pengaruh kondisi lingkungan $\left(\mathrm{X}_{1}\right)$ terhadap kemandirian belajar mahasiswa (Y) yang cukup berarti pada taraf signifikansi $\alpha=0,05$ dengan persamaan regresi linear $\mathrm{Y}=2,408+$ $0,447 \mathrm{X}_{1}$. Ini berarti bahwa setiap kenaikan satu skor pada kondisi lingkungan diikuti oleh kenaikan 0,447 skor kemandirian belajar mahasiswa pada konstanta 2,408.

Adapun koefisien regresi kondisi lingkungan $\left(\mathrm{X}_{1}\right)$ terhadap kemandirian belajar mahasiswa $(\mathrm{Y})$ adalah $\mathrm{r}_{\mathrm{y} 1}=0,540$ dan koefisien determinasi $r_{\mathrm{yl}}^{2}=0,291$ telah teruji signifikan sehingga dapat diartikan bahwa variabel kondisi lingkungan memberikan sumbangan terhadap kemandirian belajar mahasiswa sebesar $29,1 \%$.

Dengan demikian dapat disimpulkan bahwa kondisi lingkungan yang baik atau kondusif dapat meningkatkan kemandirian belajar mahasiswa. Demikian pula sebaliknya, kondisi lingkungan yang buruk dapat menyebabkan kemandirian belajar mahasiswa menurun.

Selanjutnya dari hasil analisis data terlihat adanya pengaruh motivasi $\left(\mathrm{X}_{2}\right)$ terhadap kemandirian belajar mahasiswa (Y) yang cukup berarti pada taraf signifikansi $\alpha=0,05$ dengan persamaan regresi linier $\mathrm{Y}=1,572+0,628 \mathrm{X}_{2}$. Ini berarti bahwa setiap kenaikan satu skor pada motivasi diikuti oleh kenaikan 0,628 skor kemandirian belajar mahasiswa pada konstanta 1,572 .

Adapun koefisien regresi motivasi $\left(\mathrm{X}_{1}\right)$ terhadap kemandirian belajar mahasiswa (Y) adalah $r_{\mathrm{y} 2}=0,705$ dan koefisien determinasi $r^{2}{ }^{2}=$ 0,497 yang telah teruji signifikan sehingga dapat diartikan bahwa variabel motivasi sangat berpengaruh terhadap kemandirian belajar mahasiswa sebesar $49,7 \%$.

Dengan demikian dapat disimpulkan bahwa tingkat motivasi mahasiswa yang tinggi dapat menaikkan tingkat kemandirian belajar mahasiswa. Demikian pula sebaliknya, tingkat motivasi belajar yang rendah dapat menurunkan tingkat kemandirian belajar mahasiswa.

Dari hasil analisis regresi berganda terlihat bahwa pengaruh kondisi lingkungan $\left(\mathrm{X}_{1}\right)$ dan motivasi $\left(\mathrm{X}_{2}\right)$ secara serempak terhadap kemandirian belajar mahasiswa (Y) cukup berarti pada taraf signifikansi $\alpha=0,05$ dengan persamaan regresi linier $\mathrm{Y}=1,163+0,221 \mathrm{X}_{1}+0,516 \mathrm{X}_{2}$. Ini berarti bahwa kenaikan skor pada kondisi lingkungan dan skor pada motivasi diikuti oleh kenaikan skor kemandirian belajar mahasiswa pada konstanta 1,163 .

Adapun koefisien regresi kondisi lingkungan $\left(\mathrm{X}_{1}\right)$ dan motivasi $\left(\mathrm{X}_{2}\right)$ secara serempak terhadap kemandirian belajar mahasiswa (Y) adalah $\mathrm{R}_{\mathrm{Y} .12}=0,743$ dan koefisien determinasi $\mathrm{R}_{\mathrm{Y} .12}^{2}=0,552$ telah teruji signifikan sehingga dapat diartikan bahwa variabel kondisi lingkungan dan motivasi secara serempak berpengaruh terhadap kemandirian belajar mahasiswa sebesar $55,2 \%$. Hal ini menunjukkan bahwa persentase sumbangan pengaruh variabel kondisi lingkungan dan motivasi terhadap kemandirian belajar mahasiswa sebesar 55,2\%. Sedangkan sisanya $44,8 \%$ dipengaruhi oleh variabel lain yang tidak dimasukkan dalam penelitian ini.

Berdasarkan hasil analisis tersebut dapat dilihat bahwa semakin baik kondisi lingkungan yang diikuti oleh motivasi yang tinggi maka kemandirian belajar mahasiswa akan semakin tinggi. Demikian pula sebaliknya, makin buruk kondisi lingkungan yang diikuti oleh motivasi kondisi lingkungan yang rendah maka kemandirian belajar mahasiswa juga akan semakin rendah. Dengan demikian dapat disimpulkan bahwa kedua variabel yaitu kondisi lingkungan dan motivasi mempunyai pengaruh signifikan baik secara parsial maupun secara serempak terhadap kemandirian belajar mahasiswa.

\section{KESIMPULAN}

Berdasarkan hasil analisis data penelitian dapat disimpulkan bahwa kondisi lingkungan dan motivasi berpengaruh signifikan baik secara 
parsial maupun secara serempak terhadap kemandirian belajar mahasiswa Politeknik Negeri Jember. Secara lebih rinci, hal itu dapat diuraikan sebagai berikut. Pertama, kondisi lingkungan secara signifikan mempengaruhi kemandirian belajar mahasiswa. Kedua, motivasi secara signifikan mempengaruhi kemandirian belajar mahasiswa. Ketiga, kondisi lingkungan dan motivasi secara serempak berpengaruh signifikan terhadap kemandirian belajar mahasiswa.

\section{SARAN}

Saran yang diberikan dalam penelitian ini ditujukan kepada para mahasiswa, dosen,dan seluruh civitas akademika Politeknik Negeri Jember. Para mahasiswa hendaknya selalu berupaya meningkatkan kemandirian belajar mereka dengan memanfaatkan kondisi lingkungan yang baik serta selalu berusaha memelihara dan meningkatkan motivasi dengan baik. Para dosen sebaiknya juga melakukan upaya untuk meningkatkan motivasi belajar mahasiswa, baik itu motivasi intrinsik maupun motivasi ekstrinsik. Seluruh civitas akademika seharusnya menciptakan lingkungan belajar yang kondusif agar para mahasiswa dapat meningkatkan kemandirian belajar mereka.

\section{DAFTAR PUSTAKA}

Ahmadi, Abu dan Nur Uhbiyati. Ilmu Pendidikan. Jakarta: Rineka Cipta, 2003.

Aisyiyah, Siti. "Kemandirian Belajar dan Hubungannya dengan Lingkungan Belajar serta Motivasi Belajar Siswa". Jurnal Ilmiah Inovasi, Vol.12, No.3 Edisi: September - Desember 2012. Jember: Politeknik Negeri Jember, 2012.

Arikunto, Suharsimi. Manajemen Penelitian. Jakarta: Rineka Cipta, 2007.

Edge, Julian. Essentials of English Language Teaching. New York: Longman, 1999.

Damanik, Caroline. Sistem Pendidikan Indonesia Terendah di Dunia. Kompas.Com, 2012.

Djamarah, Syaiful Bahri. Psikologi Belajar. Jakarta: Rineka Cipta, 2008.

Hakim, Thursan. Belajar Secara Efektif. Jakarta: Puspa Swara, 2000.
Hartoto. Pengertian dan Unsur-Unsur Pendidikan. 2008.

http://fatamorghana.wordpress.com/2008/ 07/11/bab-ii-pengertian-dan-unsur-unsurpendidikan/.

Keller, John M. and Brenda C.Litchfield. "Motivation and Performance", In Trends and Issues in Instructional Design and Technology. New Jersey: Pearson Education, Inc., 2002.

Kotze, Robin Stuart. Motivation Theory. 2008. http://www.goal-settingguide.com/motivation-theory.html.

Little, David. "Learner Autonomy and Second/Foreign Language Learning". Subject Centre for Languages, Linguistics, and Area Studies. 2008. http://lang.ltsn.ac.uk/resources/goodpracti ce. $\operatorname{aspx}$ ?resourceid=1409.

Moore, Kenneth D. Effective Instructional Strategies: From Theory to Practice. California: Sage Publication, Inc., 2005.

Muhidin, Sambas Ali dan Maman Abdurrahman. Analisis Korelasi, Regresi, dan Jalur dalam Penelitian. Bandung: Pustaka Setia, 2007.

Olivier, Carolyn and Rosemary F. Bowler. Learning to Learn. New York: Fireside, 1996

Rasyid, Fathor. "Strategy Training for Learner Autonomy: Language Planning and Policy Perspective". International Journal of Education. Vol.2,No.1,November 2007. Bandung: UPI, 2007.

Sanjaya, Wina. Strategi Pembelajaran Berorientasi Standar Proses Pendidikan. Jakarta: Kencana, 2007. 
Siti Aisyiyah, Pengaruh Kondisi Lingkungan Dan Motivasi Terhadap Kemandirian Belajar Mahasiswa Politeknik Negeri Jember

Sardiman, A.M. Interaksi \& Motivasi Belajar Mengajar. Jakarta: RajaGrafindo Persada, 2008.

Shadiq, Fadjar. Memupuk Kemandirian Sebagai Strategi Pengembangan Kepribadian. 2008.

http://www.acehrecoveryforum.org/librar $\mathrm{y} /$ download.php?file=Memupuk\%20Keman dirian\%20Sebagai\%20Strategi\%20Penge mbangan\%20Kepribadian.pdf.

Soedijarto. Pendidikan Nasional sebagai Proses Transformasi Budaya. Jakarta: Balai Pustaka, 2003.

Sugiyono. Metode Penelitian Pendidikan: Pendekatan Kuantitatif, Kualitatif, dan $R \& D$. Bandung: Alfabeta, 2006.

Thanasoulas, Dimitrios. "What is Learner Autonomy and How Can It Be Fostered?", The Internet TESL Journal. 2008.

http://iteslj.org/Articles/ThanasoulasAutonomy.html.

Undang-Undang Republik Indonesia Nomor 20 Tahun 2003 tentang SISIKNAS. Bandung: Citra Umbara, 2006.

Wenden, Anita. Learner Strategies for Learner Autonomy. Cambridge: Prentice Hall International (UK) Ltd., 1991.

Woolfolk, Anita. Educational Psychology. Boston: Pearson Education, Inc., 2004. 